\title{
PELATIHAN MEMANFAATKAN LAHAN SEMPIT UNTUK BUDIDAYA SAYURAN ORGANIK
}

\section{TRAINING TO UTILIZING NARROW-LAND AREA TO CULTIVATE ORGANIC VEGETABLES}

\author{
1)Aman Suyadi, ${ }^{2}$ Bambang Nugroho \\ 1,2,)Program Studi Agroteknologi, Fakultas Pertanian \\ Universitas Muhammadiyah Purwokerto \\ Jl. Raya Dukuh Waluh PO BOX 202 Purwokerto 53182 \\ Telpon: (0281)636751 ext : 130 Fax (0281)637239 \\ *Email: amanump@yahoo.com
}

\begin{abstract}
ABSTRAK
Kegiatan program IbM bertujuan meningkatkan kemampuan dan ketrampilan para kader dan anggota PKK RW 12 dan 13 kelurahan Karangklesem dalam memberdayakan lahan sempit di sekitar tempat tinggalnya dengan cara meningkatkan kemampuan dan ketrampilan penguasaan teknologi vertikultur sayuran organik mulai dari pembuatan pupuk organik, pestisida hayati, pesemaian bibit, pembuatan media tanam, penanaman, pemeliharaan tanaman, pemanenan dan pasca panen, serta kemampuan berwirausaha (agribisnis) tanaman sayuran. Tujuan selanjutnya adalah tertanganinya limbah rumah tangga, terciptanya lingkungan hijau yang asri dan estetik serta para kader dan anggota PKK RW 12 dan 13 mendapatkan penghasilan tambahan dari penjualan sayur organik.Metode yang digunakan dalam realisasi program $I_{b} M$ ini adalah pelatihan dan praktik langsung, pendampingan, pembinaan, serta kemitraan dengan para kader dan anggota PKK RW 12 dan 13 kelurahan Karangklesem. Telah dilakukan pemberdayaan pemanfaatan lahan sempit di sekitar RW 12 da 13 kelurahan Karangklesem dengan kegiatan : (1) pelatihan pembuatan bioaktivator, pupuk organik cair dan kompos. Hasil pelatihan berupa 20 liter bioaktivator, 200 liter pupuk organik cair dan $750 \mathrm{~kg}$ pupuk kompos, (2) pelatihan teknik pembuatan pestisida hayati, hasil pelatihan sebanyak 200 liter pestisida hayati, (3) pelatihan teknik vertikultur sayuran organik, dihasilkan 47set pertanaman sayuran organik dalam sistem vertikultur. (4) teknik pasca panen sayuran organik dan (5) pelatihan kewirausahaan yang meliputi pelatihan pembukuan, pelatihan analisa usaha vertikultur sayuran organik dan pelatihan manajemen pemasaran. Kesimpulan hasil kegiatan IbM adalah telah terjadi peningkatan kemampuan dan ketrampilan para kader dan anggota PKK RW 12 dan 13 kelurahan Karangklesem dalam penguasaan teknologi vertikultur sayuran organik, mulai dari pembutan bioaktivator, pupuk organik cair, kompos, pestisida hayati, pesemaian bibit, pembuatan media tanam, penanaman, dan pemeliharaan tanaman, panen dan penanganan pasca panen, serta berwirausaha tanaman sayuran.
\end{abstract}

Kata kunci: Pupuk organik, pestisida hayati, vertikultur sayuran, dan ketrampilan

\begin{abstract}
IbM program aimed at improving capability and skill of cadres and PKK members of RW 12 and 13 Karangklesem village in optimalizing narrow-land area in their neighbourhood through improving capability and skill on verticulture technology mastery on organic vegetables from the making of organic fertilizer, biological pesticide, seed seedling, planting media, planting, plant treatment, harvesting and post harvesting, and capability of vegetables (agribusiness) entrepreneurship. The next aim was to handle the household waste, to create beautiful, green, and aesthetic environment, and to earn additional income for the cadres and PKK members of $R W 12$ and 13 from their organic vegetable sales. The method used in this IbM program was training and direct practice, assisting, fostering, and partnership with the cadres and PKK members of RW 12 and 13 at Karangklesem village.Utilization of narrow-land area has been conducted around $R W 12$ and 13 at Karangklesem village by conducting the following activities: (1) Bioactivator making and liquid organic fertilizer and compost training. The
\end{abstract}


results were 20 liters bioactivator, 200 liters liquid organic fertilizer, and 750 kilograms compost, (2) the technique of making biological pesticide training; the result was 200 liters of biological pesticide, (3) organic vegetable virticultur technique training; the result was 47 sets of organic vegetables in verticulture system, (4) post-harvesting technique of organic vegetables, and (5) entrepreneurship training covering the training of book keeping, business analysis of verticulture organic vegetable and marketing management. The conclusion of this IbM program was that there was an improvement on capability and skill of the cadres and PKK members of $R W 12$ and 13 Karangklesem village in mastering the verticulture technology of organic vegetables from the making of bioactivator, liquid organic fertilizer, compost, biological pesticide, seed seedling, planting media, planting and plant treatment, harvesting and post-harvesting treatment, and organic vegetable entrepreneurship.

Keywords: organic fertilizer, biological pesticide, verticultur vegetable, and skill.

\section{Submited : 20 Maret 2017 Revision : 17 Juni $2017 \quad$ Accepted : 8 September 2017}

\section{PENDAHULUAN}

Tim Penggerak Pemberdayaan Kesejahteraan Keluarga (TP PKK) Kelurahan Karangklesem terdiri atas 25 pengurus yang berasal dari perwakilan pengurus PKK RW. TPPKK merupakan salah satu mitra pemerintah kelurahan Karangklesem dalam membangun masyarakatnya. Guna merencanakan, melaksanakan, membina, memberdayakan dan mefasilitasi program kerjanya, TP PKK membentuk 4 kelompok kerja (Pokja), salah satunya adalah pokja IV yang berperan dalam pelestarian lingkungan.

Kelurahan Karangklesem memiliki luas wilayah 302 ha, terdiri atas $13 \mathrm{RW}$ dan 67 RT, sebagian besar wilayahnya terdiri atas lahan pemukiman, perkantoran, pertokoan, pekarangan, sawah beririgasi teknis, dansebagian sawah tadah hujan(Monografi Kelurahan Karangklesem, 2013). Luas lahan pertanian di kelurahan Karangklesem semakin berkurang, hal ini disebabkan alih fungsi lahan pertanian untuk berbagai kepentingan, seperti : perumahan, industri kecil, sekolah, pertokoan, perkantoran dan sarana sosial.

Hasil survey pendahuluan oleh Tim IbM menunjukkan bahwa sejak tahun 2005 laju penyempitan lahan pertanian di kelurahan Karangklesem mencapai 0,8-2,5 ha per tahun atau sekitar $0.32-0,83$ persen, alih fungsi lahan pertanian sebagian besar untuk komplek perumahan, jumlah perumahan di kelurahan Karangklesem hingga tahun 2013 mencapai 11 komplek atau sekitar 25 ha. Menurunnya luas lahan pertanian menyebabkan menurunya produksi pertanian sementara meningkatknya jumlah penduduk harus diikuti meningkatnya produksi pertanian, hal inilah yang menyebabkan daya dukung lahan pertanian di kelurahan Karangklesem semakin berat.

Meningkatnya pendidikan, pengetahuan, dan kesadaran masyarakan akan keamanan pangan, menyebabkan tuntutan masyarakat akan pangan sehat, aman dan bergizi terus meningkat. Akulturasi antarawarga perumahandan masyarakat setempat juga meningkatkan pemahaman akan pangan sehat, aman dan bergizi. Hal tersebut mengisyaratkan bahwa peningkatan produksi pertanian harus diikuti dengan meningkatnya kualitas pangan yang aman, sehat, dan bergizi.

Upaya meningkatkan produksi pertanian di lahan sempit yang dapat memenuhi tuntutan masyarakat akan sayuran sehat, aman dan bergizi dapat dilakukan dengan budidaya sayuran organik dalam sitem bertingkat (vertikulur sayuran organik). Vertikultur sayuran organik adalah budidaya sayuran dalam pot 
yang ditempatkan pada suatu rak secara vertikal dengan memanfaatkan sumber bahan organik organik yang ada di sekitar perumahan.

Hasil survey pendahuluan oleh tim pelaksana IbM menunjukkan bahwa pemanfaatan halaman perumahan untuk bidadaya tanaman hias dan sayur telah banyak dilakukan umumnya oleh para ibu PKK dan remaja putri, termasuk oleh para kader dan anggota PKK RW 12 dan 13, namun penerapan teknologi vertikultur sayuran organik belum diterapkan karena terkendala ketrampilan dan pengetahuan mereka tentang teknologi tersebut yang belum mereka kuasai.

Permasalahan yang dihadapi para kader dan anggota PKK RW 12 dan 13 adalah kesulitan memberdayakan lahan sempit di sekitar tempat tinggalnya untuk budidaya sayuran organik secara vertikultur (vertikultur sayuran organik)juga kemampuan berwirausaha yang masih rendah sehingga potensi lahan sempit di sekitar tempat tinggalnya belum dikelola secara baik.

Kegiatan ini bertujuan meningkatkan kemampuan dan ketrampilan para kader dan anggota PKK RW 12 dan 13 dalam memberdayakan lahan sempit di sekitar tempat tinggalnya dengan cara meningkatkan kemampuan dan ketrampilan penguasaan teknologi vertikultur sayuran organik mulai dari pembutan pupuk organik, pestisida hayati, pesemaian bibit, pembuatan media tanam, penanaman, pemeliharaan tanaman, pemanenan dan pasca panen, serta kemampuan berwirausaha (agribisnis) tanaman sayuran. Tujuan selanjutnya adalahtertanganinya limbah rumah tangga, terciptanya lingkungan hijau yang asri dan estetik serta para kader dan anggota PKK RW 12 dan 13 mendapatkan penghasilan tambahan dari penjualan sayur organik

\section{METODE}

Model pembinaan ditentukan bersama antara para kader dan anggota PKK RW 12 dan 13 dengan tim IbM berdasarkan prioritas permasalahan yang akan diatasi dan potensi wilayah. Kesepakatan awal adalah pembinaan para kader dan anggota PKK RW 12 dan 13 diarahkan pada penguasaan teknologi pembuatan pupuk organik, pembuatan pestisida hayati, dan vertikultur sayuran organik serta peningkatan pengetahuan kewirausahaan.

Metode yang digunakan dalam realisasi program $\mathrm{I}_{\mathrm{b}} \mathrm{M}$ ini adalah pelatihan dan praktik langsung, pendampingan, pembinaan, serta kemitraan dengan para kader dan anggota PKK RW 12 dan 13.

\section{Pelatihan dan Praktik Langsung}

Pelatihan dilakukan dengan perkuliahan klasikal dan praktik langsung. Penyampaian materi dilakukan dengan metode ceramah, diskusi, dan simulasi. materi pelatihan meliputi:teknik pembuatan pupuk organik (teknik pembuatan bioaktivator, teknik pembuatan pupuk pembuatan pupuk organik cair danpupuk kompos), teknik pembuatan pestisida hayati,teknik vertikultur sayuran organik, teknik pasca panen sayuran organik, dan kewirausahaan pemberdayaan lahan sekitar rumah.

Praktik langsung pembuatan pupuk organik dimulai dari proses persiapan, pembuatan bioaktivator,pembuatan pupuk organik cair, dan pembuatan pupuk kompos.Praktik pembuatan pestisida hayati dimulai dari persiapan bahan, pembuatan adonan, dan penyaringan. Praktik vertikultur sayuran organik dimulai dari persiapan, pembibitan (pesemaian) sayuran, pembuatan media tanam, penanaman, pemeliharaan tanaman dan panen. Praktik pasca panen sayuran organik dimulai dari persiapan, pembersihan, pemilahan, dan pengemasan hasil panen, dan penyimpanan dan pengangkutan 


\section{Pendampingan}

\section{Pendampingan dilakukan selama proses pembuatan pupuk organik,} pembuatan pestisida hayati, vertikultur sayuran organik, dan pasca panen sayuran. Pendampingan pembuatan pupuk organik dilakukan mulai dari proses persiapan, pembuatan bioaktivator,pembuatan pupuk organik cair, dan pembuatan pupuk kompos.Pendampinganpembuatan

pestisida hayati dimulai dari persiapan bahan, pembuatan adonan dan penyaringan. Pendampingan vertikultur sayuran organik dimulai dari persiapan, pembibitan (pesemaian) sayuran, pembuatan media tanam, penanaman, pemeliharaan tanaman dan panen. Pendampingan pasca panen sayuran organik dimulai dari persiapan, pembersihan, pemilahan, dan pengemasan hasil panen, dan penyimpanan dan pengangkutan. Pendampingan dilakukan sampai dua siklus produksi dan dapat diperpanjang jika para kader dan anggota PKK RW 12 dan 13 dianggap belum mandiri, pendampingandibatasi sampai tiga kali siklus produksi (delapan bulan).

\section{Pembinaan}

Pembinaan dilakukan dengan membimbing dan memantau para kader dan anggota PKK RW 12 dan 13 setelah kegiatan pelatihan selesai, pembinaan dilakukan secara rutin setiap dua minggu, jika dibutukan, pembinaan dapat dilakukan sesuai permintaan mitra atau Tim IbM. Pembinaan juga dilakukan sampai dua siklus produksi dan dapat diperpanjang jika anggota para kader dan anggota PKK RW 12 dan 13 dianggap belum mandiri, pendampingan dibatasi hanya tiga kali siklus produksi (delapan bulan).

\section{Kemitraan}

Kemitraan diwujudkan dengan memberi bantuan modal sarana dan prasarana pembuatan pupuk organik, pestisida hayati, vertikultur sayuran organik, dan pasca panen sayuran organik. serta bantuan teknis. Bantuan modal sarana dan prasarana tersebut di atas berupa bahan dan peralatan pembuatan bioaktivator, pupuk organik cair, dan pupuk kompos, bahan dan peralatan pembuatan pestisida hayati, bahan dan peralatan vertikultur sayuran organik, yaitu bahan dan peralatan pembibitan, pembuatan media tanam, pemeliharaan, dan panen), serta bahan dan peralatan pengolahan pascapanen sayuran organik.Bantuan teknis berupa peningkatan kemampuan dan ketrampilan pembuatan pupuk organik, pestisida hayati, vertikultur sayuran organik dan pasca panen sayuran organik

\section{HASIL DAN PEMBAHASAN}

\section{Teknik Pembuatan Pupuk Organik}

Kegiatan pemberdayaan lahan sekitar rumah diawali dengan pelatihan pembuatan pupuk organik yang dilaksanakan pada hari Ahad tanggal 15 Maret 2015. Kegiatan terfokus pada pembuatan bioaktivator, pembutana pupuk organik cair (POC) dan pembuatan pupuk organik padat (kompos). Kegiatan pelatihan diawali dengan pre test dengan caramembagikan soal kepada peserta seputar materi pelatihan. Hasil pre test menunjukkan bahwa sedang untuk perilaku sikap, rendah untuk perilaku pengetahuan, dan rendah untuk perilaku psikomotorik.

Pelatihan dilanjutkan dengan pemberian materi secara klasikal, meliputi teknik pembuatan pupuk organik, kemudian dilanjutkan dengan praktik langsung, pembuatan pupuk organik, yang dimulai dari proses persiapan, pembuatan bioaktivator, pembuatan pupuk organik cair (POC), dan pembuatan pupuk padat (kompos). Praktik dilakukan dengan melibatkan seluruh peserta sehingga para peserta membuat pupuk organik. Setelah praktik langsung pembuatan pupuk organik, dilanjutkan dengan Post test, yang 
dilakukan dengan membagikan soal terdahulu (soal pre test). Hasil post tes menunjukkan bahwa telah terjadi peningkatan ketrampilan dalam pembuatan pupuk organik cair dan kompos.

Guna mempercepat transfer teknologi pembuatan pupuk organik, keterlibatan peserta selalu didampingi oleh tim pelaksana, mulai dari tahap persiapan hingga pembuatan kompos. Pendampingan dilakukan setiap minggu hingga minggu ke lima. Hasil praktik langsung berupa 20 liter bioaktivator, 200 liter pupuk organik cair dan $750 \mathrm{~kg}$ pupuk kompos.

\section{Teknik Pembuatan Pestisida hayati}

Pelatihan pembuatan pestisida hayati dilakukan pada hari kamis tanggal 23 April 2015 meliputi kegiatan persiapan dan pemilihan bahan, pembuatan adonan, penyaringan adonan. Pelatihan diawali dengan pre test, dilakukan dengan membagikan soal kepada peserta seputar pembuatan pestisida hayati.Hasil pre test menunjukkan bahwa perilaku peserta pelatihan dapat dirinci sebagai berikut: sedang untuk perilaku sikap, rendah untuk perilaku pengetahuan, dan sedang untuk perilaku psikomotorik.

Pelatihan dilanjutkan dengan pemberian materi oleh tim pelaksana secara klasikal. Materi yang diberikan adalahteknik pembuatan pestisida hayati.Setelah pemberian materi dilanjutkan dengan praktik langsung teknik pembuatan pestisida hayati, dilakukan untuk mentransfer pengetahuan dan ketrampilan kepada peserta. Praktik langsung dimulai dari proses persiapan dan pemilihan bahan, pembuatan adonan,dan penyaringan adonan. Praktik langsung diikuti oleh 14 peserta, sehingga para peserta diharapkan lebih mudah memahami dan meningkatkan ketrampilannya. Para peserta dilibatkan dalam setiap tahap kegiatan pembuatan pestisida hayati. Pendampingan oleh tim pelaksanadilakukan pada hari ke 7 dan 14 setelah praktik.Setelah praktik langsung dilanjutkan dengan Post test, hasil evaluasi menunjukkan bahwa terjadi peningkatan perilaku peserta dalam pembuatan pestisida hayati, hal ini berarti telah terjadi transfer pengetahuan dan teknologi dari pemateri kepada peserta.

Setelah pelatihan dilanjutkan dengan pemantauan dan pendampingan. Pemantauan dan pendampingan dilaksanakan dua kali yaitu pada hari Rabu, 22 Juli dan 5 Agustus 2015. Hasil pemantauan dan pendampingan menunjukkan bahwa telah terjadi transfer pengetahuan dan ketrampilan pembuatan pestisida hayati kepada peserta pelatihan. Indikator keberhasilan kegiatan ini ditunjukkan dengan kemampuan peserta menghasilkan 200 liter pestisida hayati.

\section{Pembuatan Vertikultur Sayuran Organik \\ Pembuatan demplot vertikultur sayuran organik meliputi beberapa kegiatan utama, yaitu persiapan,} pembibitan/pesemaian sayuran, pembuatan media tanam, penanaman, pemeliharaan tanaman dan pemanenan. Pembuatan demplot diikuti oleh kader dan pengurus RW 12 dan 13 sejumlah 10 orang, Setelah tahap persiapan dilakukan pembuatan vertikultur sayuran organik, meliputi pesemaian beberapa jenis sayuran, antara lain : cabe, terong, caisin, selada, bayam merah, bayam cabut, kangkung darat, bawang daun, seledri, dan kubis bunga. Pembuatan pesemaian dilakukan pada hari Senin tanggal 20 April 2015.

Setelah pembuatan pesemaian, dilanjutkan dengan pembuatan media tanam. Media tanam berupa campuran tanah dengan pupuk kompos hasil praktik langsung sebelumnya, sedangkan tanah diperoleh dari lahan sekitar rumah, perbandingan tanah dengan kompos 1: 1 . 
Semua peserta berhasil mencampur media tanam dan memasukannya ke dalam pot dalam rak vertikultur. Setiap rak vertikultur berisi 5 pot (terbuat dari peralon talang air sepanjang 2 meter). Pot disusun secara bertingkat dalam rak vertikultur.

Penanaman sayuran dilakukan dengan cara memindahkan bibit semai ke dalam pot, pemindahan dilakukan dengan cara membuat lubang tanam sesuai ukuran pot semai kemudian mengeluarkan bibit dengan menyertakan media semai dan menanamnya didalam pot. Penanaman dilakukan pada sore hari, setiap pot ditanami satu jenis tanaman sehingga dalam satu rak terdapat lima jenis sayuran. Peserta berhasil menanam sayuran dalam pot dan menumbuhkannya hingga dewasa.

Pemeliharaan tanaman meliputi kegiatan penyiraman, pendangiran, pengendalian gulma dan pengendaian hama dan penyakit. Pemeliharaan tanaman dilakukan secara mandiri oleh peserta, hasil pemantauan menunjukkann bahwa tanaman sayur dapat tumbuh dengan baik. Beberapa tanaman sayuran berumur pendek seperti caisin, selada, bayam merah, bayam cabut, kangkung darat sudah siap dipanen.

Pemantauan dan pendampingan dilakukan selama proses pembuatan demplot vertikultur sayuran organik, pemeliharaan tanaman serta panen. Pemantauan dan pendampingan dilakukan setiap 10 hari, hingga pemantauan ketiga diketahui bahwa semua peserta mampu menanam dan memeliharan tanaman sayur organik dalam sistem vertikultur. Hal ini berarti telah terjadi peningkatan sikap, pengetahuan, dan ketrapilan peserta dalam vertikultur sayuran organik.

Hasil pemantauan menunjukkan bahwa peserta mampu menumbuhkan dan memelihara sayuran organik dalam sistem vertikultur sebanyak 40 rak, Keberhasilan ini disebabkan oleh beberapa faktor, antara lain : lingkungan yang sesuai untuk budidaya sayuran organik, peserta serius dan tekun dalam setiap tahapan vertikultur sayuran organik, dan adanya pemantauan dan pendampingan secara rutin.

Pembuatan demplot vertikultur sayuran organik untuk rumah yang tidak memiliki lahan dilakukan dalam pipa peralon bulat yang digantung dipagar rumah. Peralon yang digunakan berdiameter $4 \mathrm{dim}$, panjang $1,5 \mathrm{~m}$, diberi lubang tanam sebanyak berisi 9 lubang. Media tanam berupa campuran tanah dan pupuk kompos (1:1). Penanaman benih dilakukan secara langsung (tabela), jumlah benih 2 butir per lubang tanam, jenis sayuran yang ditanam meliputi Caisin, bayam merah, sawi putih, selada, selada merah dan seledri. Pemeliharaan tanaman meliputi penyiraman setiap pagi hari, penyiangan jika ada gulma dan pengendalian hama penyakit tanaman (secara hayati) dan pemanenan. Peserta mampu menghasilkan 7 set (25 peralon gantung) vertikultur sayuran organik.Pembuatan demplot vertikultur sayuran organik dilakukan hingga tiga tahap sikluspanen. Pemantauan dan pendampingan dilaksanakan setiap 10 hari sekali sebanyak empat kali.Hasil pendampingan dan pemantauan siklus ketiga kedua menunjukkan bahwa peserta mampu menumbuhkan sayuran organik dalam sistem vertikultur hingga panen.

Kegiatan ini melibatkan dua orang mahasiswa, keterlibatan muhasiswa mulai dari persiapan bahan dan peralatan sampai pendampingan, sehingga mahasiswa terlibat pada semua tahap kegiatan vertikultur sayuran organik. Keterlibatan mahasiswa diharapkan mempermudah dan mempercepat transfer teknologi kepada khalayak sasaran, dan sekaligus sebagi wahana peningkatan kompetensi paedagogik dan kompetensi sosial mahasiswa. 


\section{Pelatihan pasca panen sayuran organik}

Pelatihan pasca panen sayuran organik dilakukan sebanyak dua kali pada hari Ahad, 23 Agustus 2015 dan hari Rabu, 23 September 2015. Pelatihan diawali dengan penyampaian materi secara lisan kemudian dilanjutkan dengan praktik langsung. Pelatihan diikuti oleh 14 ibu-ibu PKK RW 12 dan 13.

Penyajian materi pasca panen sayuran organik dimulai dari waktu panen yang tepat, cara panen, pengumpulan, sortasi, pembersihan, pengemasan, penyimpanan, dan transportasi. Setelah penyajian materi, pelatihan dilanjutkan dengan praktek langsung, mulai dari cara panen hingga pengangkutan.

Praktik langsung dilaksanakan bersamaan dengan saat panen sayuran dari setiap siklus (3 siklus), hasil pelatihan menunjukkan bahwa peserta mampu melaksanakan penangan pasca panen sayuran organik, mulai dari pemanenan hingga pengangkutan. $\mathrm{Hal}$ ini menunjukkan bahwa telah terjadi transfer pengetahuan dan ketrampilan dari pelatih kepada peserta. Hasil panenan sayuran organik setiap siklus penanaman mencapai $4,25 \mathrm{~kg}$ per rak vertikultur dan 3,5 per 3 set vertikultur gantung.

\section{Pelatihan kewirausahaan}

Pelatihan kewirausahaan dilaksanakan pada hari Jum'at tanggal 31 Agustus 2015, dihadiri oleh 12 peserta yang terdiri atas pengurus inti PKK RW 12 dan 13. Nara sumber adalah praktisi kewirausahaan di kabupaten Banyumas. Pelatihan kewirausahaan meliputi kegiatan : teknik analisa usaha tani dan model pemasaran hasil pertanian.

untuk mengetahui peningkatan pengetahuan dan teknologi pemanfaatan lahan sempit untuk budidaya sayuran
Pemberian materi dilakukan secara klasikal, meliputiteknik analisa usaha tani dan model-model pemasaran hasil pertanian. Selama pemberian materi dilakukan tanya jawab dan diskusi, baik antara peserta dengan pemateri maupun antar peserta, sehingga menciptakan suasana keharmonisan yang lebih erat, cara ini mampu mengatasi kesulitan yang timbul selama pelatihan.

Setelah penyajian materi secara klasikal dilanjutkan dengan praktik langsung kewirausahaan. Praktik langsung dimulai dari cara menghitung biaya produksi, menetapkan harga jual, mencatat hasil penjualan, menyusun laporan keuangan, mengenal model pemasaran hasil pertanian, dan upaya meningkatkan volume penjualan.

Kegiatan pelatihan melibatkan para peserta secara aktif sehingga peserta lebih cepat paham dan ketrampilan terlihat semakin meningkat, keterlibatan peserta pada setiap tahap selalu didampingi oleh tim pelaksana sehingga transfer pengetahuan dan teknik kewirausahaan berjalan lebih cepat . Hasil evaluasi menunjukkan bahwa telah terjadi peningkatan pengetahuan dan ketrampilan kewirausahaan peserta, hal ini berarti telah terjadi transfer pengetahuan dan teknik kewirausahaan dari pemateri kepada peserta,

Selanjutnya evaluasi terhadap seluruh tahapan kegiatan Ibm dilaksanakan pada Rabu, 30 September 2015. Evaluasi dimaksudkan untuk mengetahui ketercapaian target luaran kegiatan program IbM, selain itu juga dimaksudkan

organik, hasil evaluasi disajikan pada tabel berikut : 
Tabel. Hasil Evaluasi Pelaksanaan Program IbM tahun 2015

\begin{tabular}{|c|c|c|c|c|}
\hline \multirow{2}{*}{ Aspek } & \multirow{2}{*}{ Target } & \multicolumn{3}{|c|}{ Capaian } \\
\hline & & Tahap 1 & Tahap 2 & Total \\
\hline Bioaktivator & - & 20 liter & - & 20 liter \\
\hline Produksi pupuk organik cair & 200 liter & 100 liter & 100 liter & 200 liter \\
\hline Pupuk kompos fermentasi & $500 \mathrm{~kg}$ & $500 \mathrm{~kg}$ & $250 \mathrm{~kg}$ & $750 \mathrm{~kg}$ \\
\hline Pestisida hayati & 200 liter & 100 liter & 100 liter & 200 liter \\
\hline Pertanaman vertikultur sayuran organik & 40 set & 20 set & 27 set & 47 set \\
\hline \multicolumn{5}{|l|}{ Produksi sayuran organik : } \\
\hline Rak Vertikultur & & \multicolumn{2}{|c|}{$4,25 \mathrm{~kg} / \mathrm{set}$} & $4,25 \mathrm{~kg} / \mathrm{set}$ \\
\hline Vertikultur gantung & & \multicolumn{2}{|c|}{$3,5 \mathrm{~kg} / \mathrm{set}$} & $4,25 \mathrm{~kg} / \mathrm{set}$ \\
\hline $\begin{array}{l}\text { Ketrampilan membuat pupuk organik dan } \\
\text { pestisida hayati }\end{array}$ & $\begin{array}{l}\text { Meningk } \\
\text { at }\end{array}$ & Meningkat & Meningkat & Meningkat \\
\hline $\begin{array}{l}\text { Kemampuan membudidayakan tanaman } \\
\text { sayuran organik dalam sistim vertikultur }\end{array}$ & $\begin{array}{l}\text { Meningk } \\
\text { at }\end{array}$ & Meningkat & Meningkat & Meningkat \\
\hline $\begin{array}{l}\text { Kemampuan melakukan manajemen dan } \\
\text { analisa usaha pemberdayaan lahan sempit }\end{array}$ & $\begin{array}{l}\text { Meningk } \\
\text { at }\end{array}$ & Meningkat & Meningkat & Meningkat \\
\hline
\end{tabular}

Tabel tersebut menunjukkan bahwa program IbM secara umum berjalan dengan baik dan capaian memenuhi target yang ditetapkan bahkan capaian beberapa aspek melampaui target yang tetapkan, sehingga dapat disimpulkan bahwa kegiatan ini berhasil dengan baik. Keberhasilan ini karena kerjasama yang baik antara tim pelaksana dengan mitra peserta.

\section{SIMPULAN}

\begin{abstract}
Kesimpulan hasil kegiatan IbM adalah telah terjadi peningkatan kemampuan dan ketrampilan para kader dan anggota PKK RW 12 dan 13 kelurahan Karangklesem dalam penguasaan teknologi vertikultur sayuran organik, mulai dari pembutan bioaktivator, pupuk organik cair, kompos, pestisida hayati, pesemaian bibit, pembuatan media tanam, penanaman, pemeliharaan tanaman, dan pemanenan dan penanganan pasca panen.
\end{abstract}

\section{DAFTAR PUSTAKA}

Cahaya, A \& Nugroho, D., (2008). Pembuatan KomposDengan Menggunakan Limbah Padat
Organik (Sampah Sayurandan Ampas Tahu). Laporan Penelitian. Universitas Diponegoro.

Indriani, Y.H. (2003). Membuat Kompos Secara Kilat. Jakarta : Penebar Swadaya.

Musnamar, E. I. (2006). Pupuk Organik : Cair dan Padat, Pembuatan Aplikasi. Depok : Penebar Swadaya.

Soeryoko, H. (2011). Kiat Pintar Memproduksi Kompos dengan Pengurai Buatan Sendiri. Yogyakarta : Lily Publisher.

Susetya, D. (2011). Panduan Lengkap Membuat Pupuk Organik. Yogyakarta : Pustaka Baru Press.

Suyadi, A. dan Agus M. P. (2012). Pengembangan Bioaktivator Berbahan Lokal Untuk Perolehan Metode Kompos Fermentasi. Laporan Penelitian. Universitas Muhammadiyah Purwokerto. 